\title{
Religion, fantasyfilm og fantastiske væsener:
}

\author{
Mediering af religion i Fantastic Beasts and Where to Find \\ Them $^{1}$
}

LAURA FELDT

ENGLISH ABSTRACT: This article discusses the nexus of religion and media on the basis of an analysis of one example of religion in popular culture: the expansion of J.K. Rowling's Harry Potter series in the book Fantastic Beasts and Where to Find Them (2001) and the subsequent film by the same title connected to the book (directed by David Yates, screenplay by J.K. Rowling 2016). I present a study of religion-based, mediafocused approach to film analysis that distinguishes between verbal and non-verbal aspects of mediation. The analysis treats the mediation of religion - traditional religion, magic and monstrous beings - in the film, as well as the mediality of the film. The analysis shows that the film forms part of a broader trend that portrays traditional religion as ossified and authoritative, while magic, monsters and green religion are represented as fascinating and attractive. Moreover, I argue that the mediality of the film sustains a blurring of boundaries between worlds in terms of the film-internal world structure, in terms of the diegetic vs. the afilmic world, and in terms of the human vs. the nonhuman world. The key argument of the article is that pop-cultural media constitute an important arena for religion, as media such as fantasy films both reflect and form religious transformations today. This arena needs more attention in the study of religion.

DANSK RESUME: Denne artikel diskuterer religion og medier ud fra en analyse af et eksempel på religion i populærkultur, nemlig en videreudvikling relateret til J.K. Rowlings Harry Potter univers: udgivelsen af bogen Fantastic Beasts and Where to Find Them (2001), en bog der er fiktivt indlejret som undervisningsbog på Hogwarts School

${ }^{1}$ Jeg præsenterede et udkast til denne artikel ved DASR/RvT-seminaret om religion og medier i december 2018 og jeg takker for gode kommentarer ved den lejlighed. Jeg vil også gerne takke de kandidatstuderende på holdet Religion, medier og populærkultur på Religionsstudier, SDU, efteråret 2019, hvor vi diskuterede mange relevante problematikker relateret til religion og film. Jeg skylder Rie Førstø en særlig tak for at have lånt mig sin 2001-udgave af Fantastic Beasts. 
of Wizardry and Witchcraft, og den senere filmatisering der knytter sig til bogen, Fantastic Beasts and Where to Find Them (instrueret af David Yates, screenplay af J.K. Rowling 2016). Artiklen præsenterer en religionsvidenskabelig, mediefokuseret tilgang til filmanalyse, der inkluderer både verbale og non-verbale medierings-aspekter. Analysen behandler fremstillingen af religion - hhv. traditionel religion, magi og det monstrøse - $i$ det filmiske univers, samt filmens medialitet. Analysen viser, at filmen indlejrer sig $i$ en bredere trend, hoor traditionel religion fremstilles som forstenet og autoritær, mens magi, monstre og gron religion fremstilles positivt og tiltrækkende, samt endvidere at filmens medialitet understøtter en udviskning af grænserne mellem verdener både $i$ den tekst-interne verdensstruktur, mellem den diegetiske og den afilmiske verden, samt mellem den humane og den non-humane verden. Artiklen argumenterer grundlæggende for at populærkulturelle medier såsom fantasyfilm udgør en vigtig arena for religion, og at denne arena bør behandles religionsvidenskabeligt, da den både afspejler og former religiøse forandringer $i$ samtiden.

KEY WORDS: Religion og populærkultur; medier; fantasyfilm; Harry Potter; Fantastic Beasts; magi; grøn religion; samtidsreligion.

\section{Indledning}

Fantasy og fantastiske væsener fylder samtidens populærkultur, og i mange forskellige medietyper ser vi nye repræsentationer, rammesætninger af og former for magi, myter og religiøse udtryk myldre frem. Fantasyfiktion, som engang var en nichegenre, en del af et nørdsegments kulturelle praksisser, er nu blevet en central del af massemedieret populærkultur på multimediale platforme. I denne artikel vil jeg diskutere religion og medier baseret på en analyse af et udvalgt eksempel på multimedial fantasyfiktion. Jeg kigger på hvordan 'religion' medieres i David Yates' filmatisering af J. K. Rowlings bog Fantastic Beasts and Where to Find Them og relateret materiale. Samtidigt præsenterer artiklen en tilgang til religion og film, som forsøger at tage mediet alvorligt $\mathrm{i}$ analysen. Jeg argumenterer for at vi i denne case ser et eksempel på hvordan fantasygenren er med til at afspejle og forme religiøse interesser og religiøs fascination i samtidens samfund i en retning, hvor institutionaliseret religion fremstilles negativt, mens magi, det monstrøse, og grøn religion fremstilles positivt. Samtidigt viser analysen, at film-mediet i særlig grad kropsligt og affektivt understøtter den form for mediering som fantasyromanen også lægger op til, og som endvidere i særlig prægnant grad understreges i bogudgaven af Fantastic Beasts, nemlig en udviskning af grænser mellem verdener. Det gælder både grænserne mellem den almindelige hverdagsverden og den anden, magiske verden, men også mellem den diegetiske verden og den afilmiske verden samt mellem det humane og det non-humane, dyriske og monstrøse - samt en fejring af disse udviskede grænser.

Fantasygenrens overvældende tilstedeværelse og popularitet i samtidens populærkulturelle medier (Game of Thrones, Vikings, Magicians, Wonder Woman, osv. for blot at nævne nogle ganske få nyere eksempler) udgør et nyt felt for repræsentationer af religion. Virtuelle og multimediale fantasy-verdener udgør i samtidens europæiske 
og nordamerikanske samfund betydningsfulde arenaer for udforskning af ideer, værdier, holdninger og meninger relateret til det religiøse felt (Feldt 2016a + b). I disse udbredte forestillingsuniverser (jfr. Gilhus \& Mikaelsson 2001, 26-32) optræder mange elementer, der falder ind under 'religion' som fagterm, og brugerne forholder sig til disse forestillingsuniverser aktivt og tilbagevendende, som regel i deres fritid, men på måder der ikke nødvendigvis stemmer overens med velkendte forståelser af religion. Brugerne går ud og ind af disse verdener, lader dem styre eller påvirke deres liv i større eller mindre grad, eller opsøger dem blot nu og da. Således mangler vi i forhold til disse forestillingsverdener nogle af de karakteristika, der ofte indgår i standardmodeller for hvad religion er, fx religions systematiske karakter, dens dybde og forpligtelse, socialt og psykologisk, samt gentagne ritualer (aspekter som fx betones hos Clifford Geertz 1977; Armin W. Geertz 1999; Flood 1999: 50). ${ }^{2}$ I denne artikel vil jeg alligevel fremhæve sådant materiales relevans for diskussioner om religion i samtiden. Jeg trækker på Gilhus og Mikaelssons definition af religion som "menneskers forhold til forestillingsunivers som kjennetegnes av kommunikasjon om og med hypotetiske guder og makter" $\left(2001,29^{3}\right)$, da den med formuleringen "om" åbner for, at undersøgelser af kommunikation om religion (guder, magter o.a. væsener, steder, ting, praksisser) i samfundet som del af et flydende kulturfelt også er en naturlig del af det religionsvidenskabelige arbejdsområde, da også sådanne typer af kommunikation er med til at skabe og vedligeholde det religiøse felt i et givent samfund (2001, 29). Denne indgang åbner også for at 'religion' ${ }^{4}$ kan være noget man kun beskæftiger sig med i fritiden, noget forholdsvist uforpligtende og sammenblandet med andre ting (jfr. argumentet i Feldt 2016a). Analysen der præsenteres her, er således på den ene side et eksempel på en analyse af religions forekomst i en populær arena, hvor der kommunikeres om hypotetiske guder, væsener, kræfter og magter; på den anden side vil analysen via et fokus på de mediemæssige aspekter af kommunikationen forsøge at nærme sig filmenes potentielle formative kraft. På baggrund af analysen diskuteres religion og medier i samtiden. Jeg starter med en præsentation af det perspektiv på medier som anvendes her.

\section{Religion og medier: multimedialitet, filmmediet og Harry Potter- universet}

Denne artikels materiale falder inden for et felt, som de fleste nok umiddelbart vil forstå som 'medier', nemlig moderne massemedier som bøger, film, facebook og twitter, o.lign., som ofte analyseres vha. Hjarvards teori om religionens medialisering i

2 Jeg ser her bort fra de kendte eksempler på nye religiøse bevægelser, der knytter sig til fantasyværker, se her fx Davidsen 2010.

3 Gilhus og Mikaelsson siger uddybende at samfundsaspektet er implicit i definitionen da alle former for kommunikation sker i en social og kulturel kontekst $(2001,29)$.

4 Jeg mener her lige præcis 'religion', ikke 'en religion', og slet ikke 'Religion'. 
senmoderne tid (Hjarvard 2012), ${ }^{5}$ som anskuer medialiseringens effekter som en individualiserende og forbrugerorienteret tilgang til det religiøse felt. Jeg vil i denne artikel i stedet trække på teorier om religion og medier i bredere forstand (jfr. indledningen til dette særnummer (Feldt \& Geertz 2020), Grieser \& Johnston 2017; Meyer 2014; Morgan 2011 m.fl.; se også Feldt \& Bremmer 2019), samt religionsvidenskabelige teorier om religion og film der arbejder med filmmediets formative magt (Plate 2017; Wright 2007).

Som præsenteret i indledningsartiklen (Feldt \& Geertz 2020) arbejder de nævnte medieteorier ud fra en antagelse om at al kommunikation er medieret - i tale, kropssprog, skrift, dans, billeder, osv. - og at dette naturligvis også gælder religiøs kommunikation. Artiklen anvender således samme brede mediebegreb som i indledningsartiklen, hvor jeg forstår medium som "any device that facilitates communication and enables relations, including social structures and traditions" (Meyer 2014). Jeg vil således analysere de særlige mediemæssige karakteristika som præger modtagelsesprocessen af filmen, selvom forskellige aktører stadig kan bruge medier kreativt og taktisk, og uden at brugernes mediebrug er genstand for analyse her; analysen bevæger sig alene på niveau af bogens og filmens kommunikation og medialitet. Artiklen tilgår altså medier som konstellationer af 'indhold-i-form', som har materielle, fysiske, sansemæssige, sociale og teknologiske karakteristika som kan beskrives og analyseres, og ser på de specifikke mediers interne og delvist eksterne konditionering, betingelser og karakteristika som præger receptionen og den sociale brug. ${ }^{6} \mathrm{I}$ dette tilfælde har vi en europæisk og nordamerikansk populærkulturel mediekultur, der fremmer religionsmediering på særlige måder. Det medium, jeg vil behandle her, er filmmediets mediering af religion i en multimedial kontekst, hvilket min case er et særligt velegnet eksempel på. Derfor vil jeg præsentere en religionsvidenskabelig, mediefokuseret tilgang til film.

Melanie Wright har påpeget, at religion på film ofte er blevet analyseret som tekst via spørgsmål om hvordan religion repræsenteres i film, snarere end på måder der tager filmmediet alvorligt som medium (Wright 2007, 20-21). Wright påpeger at analyserne ofte fokuserer på repræsentation og på det grundlæggende narrativ; det er sjældent at analyserne inddrager mediespecifikke elementer som mise-en-scène, cinematografi, redigering eller lyd (Wright 2007, 21). Det er problematisk, fordi film i sagens natur medierer kommunikation ikke kun via skrevne tegn, men visuelt, auralt og verbalt samtidigt (Wright 2007, 21). Wrights forslag går i stedet på at inddele en filmanalyse i fire led: 1) narrativ, 2) stil, 3) kulturel og religiøs kontekst og 4) reception

5 Se også L.I. Lieds og M. Lövheims kritiske diskussion af teorien i samme bind (Hjarvard og Lövheim 2012).

6 Jfr. Feldt og Geertz 2020 fremgår det at artiklen placerer sig inden for feltet af medie-teorier i relation til teorier om medier som teknologier (McLuhan 1994; Meyrowitz 1994; Meyrowitz 2001, 10). Jeg anvender termen medium til at henvise til én form for mediering og et særligt medium i en bestemt kulturel kontekst, mens flertalsformen medier og termen multimedialitet anvendes til at understrege hvordan flere medier arbejder sammen, mhp. at kunne iagttage komplekse gensidige relationer mellem medier. Termen mediekultur anvendes til at henvise til en interaktion mellem kulturelle faktorer og kommunikationskontekster, hvor nogle former for mediering - og de former for socialt liv de fremmer - kan dominere i nogle epoker og kontekster (Mahan 2014, 3-16). 
som én måde at tage mediespecifikke aspekter mere alvorligt i analysen. Wrights' narrative analyse ligger i forlængelse af klassiske analysemodeller inden for narratologien, da dette led fokuserer på karakterer, story, og plotting, mens Wrights 'stil' omfatter æstetiske og audiovisuelle dimensioner, inkl. mise-en-scène, cinematografi, redigering og lyd - dvs. hvad vi kunne kalde de mediemæssige dimensioner, mens kontekst- og receptionsanalyse er umiddelbart velkendte aspekter fra et religionsvidenskabeligt perspektiv.

I tillæg til sådanne elementer tager Brent Plate yderligere mediemæssige aspekter op. Plate peger på de mange verdens/virkeligheds-lag som filmmediet relaterer til. Det er ikke nok at diskutere narrativet eller de verbale aspekter; en filmanalyse må tage flere verdener i betragtning. Således skelner Plate mellem flere verdener eller lag som analysen må tage fat $\mathrm{i}$ - som minimum den afilmiske verden (den verden der eksisterer uafhængigt af den filmiske verden), den diegetiske verden (den fiktive verden skabt af filmen), tilskuerverdenen (tilskuerens opfattelse og forståelse af en film), samt skaberverdenen (filmskaberens intentioner). ${ }^{7}$ Han påpeger således, at der via filmmediet sker en aktivering af tilskuerens krop der udvisker grænserne mellem den symbolske/diegetiske verden og den hverdagslige/afilmiske verden yderligere eller mere intenst end hvad der måtte ske via andre form/indholdskonstellationer: Ved film-kigning får den symbolsk forestillede verden et konkret kropsligt aspekt, de "sensations" som relaterer til den symbolske verden, får en kropsligt oplevet plads i den almindelige, hverdagslige verden, fordi de kropsligt-mimetiske reaktioner ved audiovisuelle medier er stærkere end ved andre, fx litterære, medier. Den audiovisuelle oplevelse af film bevæger tilskuernes kroppe; det er tydeligt at se tilskuernes opslugthed af begivenhederne på lærredet - ved pludselige begivenheder rykkes kroppe tilbage i sæderne, man smiler med ved lykkelige begivenheder; tåreperserfilm har ikke dette tilnavn uden grund. Den film-tilskuende krop er således en ret aktiv krop (Plate 2017, 98-99), og filmmediet har således særligt stærke mediemæssige, sanselige, mimetiske effekter. Plate påpeger videre, at film skaber forestillingsverdener / symbolske verdener ved at filtrere, indramme og selektere, sortere og kategorisere udtryk. Så når den sansende krop mødes med de audiovisuelle impulser, må vi således tage to medier med i betragtning: det ene er film-mediet; det andet er kroppen. Som andre medier filtrerer, selekterer, indrammer, glemmer og forudsiger kroppens sanser også indtryk. Sanserne medierer udefrakommende indtryk i den menneskelige krop (Plate 2017, 101-102; Plate 2012), og sanserne er aktive. ${ }^{8}$ Med begge disse former for mediering er vi i religionsæstetikkens område (Grieser \& Johnston 2017). ${ }^{9}$ Megen sanseperception foregår selvfølgelig ubevidst (jfr. Taves \& Asprem 2020), men

7 Plate trækker her på filmteoretikeren Étienne Souriaus i alt syv virkelighedslag i relation til film (Plate 2017, 13).

8 Sanse-erkendelse bliver som Plate påpeger trænet kulturelt fra barndommen og er baseret på "hardwired neurological matter," så hvordan vi ser, føler og smager er selvfølgelig socialt konstrueret - men selvfølgelig ikke kun socialt konstrueret. Et fokus på æstetik peger på kroppens sanser som et helt grundlæggende "worldmaking locus" (jfr. Taves \& Asprem 2020; Feldt 2020; Plate 2017, 102103).

$9 \quad$ Estetik forstås her som aisthesis, sansning. 
fordi vi foretager mere eller mindre bevidste valg vedr. hvilke filmgenrer vi foretrækker at se (som fx fantasy), så kan disse valg medføre en sanse-træning. Film både viser og skaber en "sensation", og fremviser, skaber og træner emotioner mimetisk (Plate 2017, 103, jfr. Damasio 1994). Sådanne former for følelsesmæssig stimulans - som trænes ved hyppig brug - bringer erfaringer, tanker, sansninger, følelser og handlinger sammen på måder der ikke altid kan udtrykkes sprogligt eller bevidst, som Schaefer påpeger (Schaefer 2015, 3; Plate 2017, 103-104).

Ift. den filmoplevende krop står vi således med endnu en form for overlap i tillæg til de overlap, som jeg har antydet at analysen viser at FB-filmens kommunikation og fantasygenrens medialitet tematiserer og som vi vender tilbage til om lidt: dobbeltperspektivet af kroppen der ser og hører i en kontekst eller verden, samtidigt med at den fanges ind af den audiovisuelle fortælling, af en anden verden (Plate 2017, 104). Filmtilskueren er således splittet mellem flere perspektiver på én gang: (mindst) mellem den diegetiske og den afilmiske verden, dvs. filmkigningens oplevelseskontekst, hvor de diegetiske begivenheder på den ene side er fiktive, og den afilmiske verden hvor den bedste filmoplevelse er afhængig af at man på den anden side kropsligt 'foregiver' at begivenhederne ikke er fiktive (Plate 2017, 105). ${ }^{10}$ Horrorfilmen er her et illustrativt eksempel - som tilskuer kan man forsøge at læne sig tilbage, gemme sig bag avisen og ikke lade sig påvirke af filmen, men den sansende krop reagerer alligevel på slim og zombier, og desto bedre jo mere man engagerer sig i filmkigningen og netop ikke gemmer sig bag avisen. Tilskueren ved godt at pigen i Eksorcisten ikke reelt er dæmonbesat, men kroppen handler som om hun var. Den æstetiske sanselighed trumfer som regel en bevidsthed om fikticitet ${ }^{11}$ kropsligt i kortere eller længere tid, og filmens effekter sidder i tilskueren et stykke tid og infiltrerer hverdagslivet 'et eller andet sted' (på samme måde som et veludført ritual sidder i kroppene et stykke tid, fristes man til at påpege). Dette 'et eller andet sted' hinsides det sproglige kalder Plate "the sensing body in motion" (Plate 2017, 105-106). Kroppenes reaktioner er en slags overlap, der etableres mellem forestillingsverdenen og hverdagsverdenen, den splittede opmærksomhed mellem den fortalte verden og oplevelseskonteksten, og de måder hvorpå de sansede lyde og billeder forbliver i krop og bevidsthed et stykke tid. Disse overlap mellem verdener, udviskningen af grænser og den splittede opmærksomhed gør det vanskeligt entydigt at kalde den fortalte, filmiske verden og filmoplevelsen for entydigt $u$ virkelig, og oplevelseskonteksten og hverdagskonteksten for entydigt virkelig. ${ }^{12}$

Jeg har valgt at operationalisere ovenstående indsigter fra Wright og Plate på den måde at jeg deler medieanalysen op i en kontekstualiserende del og en filmspecifik

10 Som Plate bemærker er dette lig myter og ritualer: Deltagerne er ofte splittet mellem en bevidsthed om at den religiøse myte ikke er faktuel, og at fortællingen kunne være sand ('på en måde', 'et eller andet sted', 'på et andet plan', 'på en særlig måde'), samtidigt med at de ritualiserende kroppe handler som om den var (Plate 2017, 105).

11 For indgående diskussioner om religiøse fortællinger og fiktion, se Davidsen, ed., særnummer af Religion, 2016.

12 Her kan det være relevant at sammentænke med Ricoeurs tanke om poesiens og metaforens splittede reference (se her Ricoeur 1975, kap. 8). 
del; begge er dog fokuseret på spørgsmålet om filmens mediering af religion. Religion er her bredt forstået, dvs. også omfattende fantastiske og monstrøse væsener, magikere, m.m. (jfr. Feldt 2016a og b). I den første del af analysen kigger jeg på de mediekulturelle og kontekstuelle rammer for filmen, dvs. fantasygenrens medialitet, den generelle multimedialitet der kendetegner mediekulturen i dag, og det Potterske narrative forestillingsunivers filmene knytter an til, samt den førstudgivne bog som var et spin-off af en fiktiv skolebog indlejret i Harry Potter-serien. I den film-specifikke del af analysen analyserer jeg filmenes fremstilling af "religion" ud fra Plates verdensdistinktioner og en basal skelnen mellem verbale aspekter, herunder replikker, narrativ, m.m., og non-verbale film-mediale aspekter som mise-en-scène, lys, lyd, farve, rekvisitvalg o.lign. Sluttelig forsøger jeg at vurdere filmens samlede mediering af religion.

\section{Filmanalyse I: kontekstualiserende del}

Først vil jeg kort udpege nogle interne karakteristika ved fantasy-genren som medium, dvs. som en form-indholds-konstellation. En egentlig medieanalyse skal selvfølgelig kombineres med de eksterne karakteristika, dvs. fysiske, sansemæssige, sociale osv. som fantasy da også får i bestemte udmøntninger som bøger eller film; men disse tager analysen op bagefter i relation til det særlige eksempel på fantasy der analyseres her. Form-indholds-konstellationen for fantasygenrens vedkommende er så forholdsvist fasttømret at den kan antages at påvirke receptionsprocessen. ${ }^{13}$

Genrehistorisk udspringer den fantastiske litteratur, horror- og fantasygenrerne fra den gotiske tradition, ${ }^{14}$ der videreudvikledes ind i det 19. årh., hvor fantasyfiktionen opstod som selvstændig, moderne genre: litteraturværker domineret af alternative verdener, med 'overnaturligt' indhold (magi, monstre, profetier, o.a.), præget af en kamp mellem godt og ondt og en helt, der kæmper det godes sag. Genren nåede et første højdepunkt midt i det 20. årh.; ${ }^{15}$ men i dag kan Harry Potter-serien anses for at være det mest udbredte, læste og solgte fantasyværk til dato (Feldt 2012, 43-44). Sammenlignet med andre litterære genrer har fantasyfiktion mediekvaliteter som gør den særligt oplagt til religiøs brug og religiøse reaktioner: Indholdsmæssigt ligner fantasy religiøse fortællinger som myter, eper o.a. med transempiriske, overmenneskelige begivenheder, aktører, handlinger, rum, genstande, m.m. (Feldt 2016a, 103-104). Eftersom religion som bekendt ikke er begrænset til at handle alene om traditionelle guder og organiserede religioner, så falder et indhold som forfædredyrkelse, spøgelser, profetier, magi osv. ind under religionsfeltet (jfr. McGuire 2008; Partridge 2004-6;

13 Den følgende sektion af artiklen overlapper med tidligere karakteristikker af fantasygenren (2012, 43-45; Feldt 2016a).

14 Horace Walpole's The Castle of Otranto, 1764, nævnes normalt som den første gotiske fortælling (Wisker 2005, 15; Simonis 2005, 31).

15 C.S. Lewis og J.R.R. Tolkien udgav begge deres hovedværker i 1950erne. 
Sutcliffe \& Gilhus 2013). ${ }^{16}$ Formmæssigt finder vi også et overlap mellem fantasyfortællinger og religiøse fortællinger. Nogle forskere har foreslået at religiøse tekster er særlige, fordi de insisterer på at deres fantasmer er sande eller virkelige; ${ }^{17}$ men som tidligere udpeget (Feldt 2006; 2016) så kan dette ved nærmere undersøgelse ikke fungere som afgørende parameter. Forsøget på at skabe et overlap mellem den tekstinterne og den tekst-eksterne verden ses af nogle fantasyforskere som et af kendetegnene på fantasy; særligt er forsøg på at få læseren til at undre sig over om tekstens begivenheder virkelig har fundet sted eller ej, karakteristisk for genren (Lachmann 2002, 137). ${ }^{18}$ Af yderligere formmæsige kendetegn ser vi også i fantasy - som i mange religiøse fortællinger - en underliggende kosmologi og antropologi som er formålsbestemt og teleologisk. En verden præsenteres i hvilken en usynlig magt opererer bag scenen (Feldt 2016a, 103-104), og hvor der ikke er tale om mekaniske årsag-virkningsstrukturer eller om et tilfældighedsprincip, men snarere om en forsynsstruktur indbygget i verden, som medfører at handlinger, begivenheder og beslutninger tager del i en højere orden, ${ }^{19}$ som lægger op til tanken om at en højere magt eller kraft står bag verden - som regel dog uden at denne magt eller kraft deltager som aktør i fortællingen. ${ }^{20}$ Denne form-indholds-konstellation giver den typiske fantasyheltinde/-helt et kosmisk ansvar, hvilket forklarer det stærke fokus i fantasy på heltens valg. Så selvom social kontekst, rituel brug og institutionel sanktion kan gøre alt 'religiøst' (Fields 1995), så gør denne konstellation det mere sandsynligt at fantasylitteratur vil tiltrække religiøs opmærksomhed og brug end andre genrer (Feldt 2006, 2012, 2016a; se også Davidsen 2016; Petersen 2016).

Fantasy er en nabogenre til horror, som kan defineres som en genre der stimulerer "intense repugnance, fear or dread" (Encyclopedia Britannica, s.v. Horror film; se også Wisker 2005). Fantasy er på lignende måder blevet forstået ud fra dens tilskrevne stimulering af en følelsesmæssig reaktion: som en genre, der vækker undren hos læseren, i tilfældet den fantastiske fortælling, en kognitiv tøven (Todorov 1975), eller en Schwebezustand mellem mulige forklaringer (Lachmann 2002, 138). Encyklopædiopslaget om horrorfilm nævner videre indholdsrelaterede genretræk, såsom fysisk vold, psykotiske og onde karakterer, skrækindjagende monstre og ondsindede dyr.

16 Som Kelso demonstrerer så præsenteres traditionelle religioner ofte som impotente og forstenede i fantasygenren, mens magikere præsenteres som åndeligt potente figurer (Kelso 2007, 65-66. 70. 725). Det vil altså sige at dele af fantasylitteraturen deltager i en diskursiv religiøs 'kamp' på magiens og åndelighedens side over for traditionel, institutionaliseret religion.

17 If. Petersen $(2005,17)$ er dette et af distinktionskriterierne for religiøse tekster. Men nogle typer af fantasy og fantastisk litteratur præsenterer sig som fortællinger om faktiske begivenheder, jf. Horace Walpole - og Todorov (1975, 27-28). Se også Feldt 2006 and 2012 samt diskussionen mellem Davidsen, Petersen og Feldt i særnummeret af Religion 2016 (Davidsen ed. 2016).

18 Samtidigt findes der jo utallige religiøse tekster som ikke bringer spørgsmål om relationerne til den teksteksterne verden op, mens der også findes religiøse kontekster i hvilke en teksts 'fiktionalitet' ikke er et problem (Feldt 2012, 242-254; Feldt 2011). Bemærk at Lachmanns definition er bred og modusbaseret og inkluderer fantasy (Lachmann 2004, 7-26). Forfatterkriteriet er heller ikke afgørende, fordi religiøse tekster ofte tilskrives konkrete menneskelige forfattere og redaktører.

19 Se også Lachmann (2004, 117-118. 125).

20 Både Tolkiens og Lewis' fantasypoetikker viser forfatternes eksplicitte refleksioner over dette (se Tolkien 1964). 
Her nærmer vi os noget, der er karakteristisk for netop den film, jeg vil se på her, nemlig at den tager det monstrøses traditionelt negative italesættelse eksplicit op. Filmen rekalibrerer så det monstrøse i positiv, fascinerende og omsorgsvækkende retning, som vi skal se.

I dag er fantasyfiktion desuden et multimedialt felt, hvor bogudgivelser følges naturligt af filmversioneringer, tv-serier, merchandise, hjemmesider, fan-diskussionsfora, digitale spil, m.m. Fantasy er i dag uomtvisteligt både mainstream og et massefænomen. Uden at jeg har foretaget nogen form for kvantitativ undersøgelse, virker det rimeligt at påpege et endog meget stort fantasy-fokus i samtidens vestlige mediekultur. For Harry Potter-universets vedkommende kan multimedialiteten opsummeres i termen The Potterverse, en samlebetegnelse for den meget store mængde af forskelligartet materiale relateret til Rowlings oprindelige bogserie (1995-2000): ${ }^{21}$ filmatiseringer, digitale spil, brætspil, merchandise, tøj o.a. udstyr fra kopper til koste og kapper, LEGO-legetøj, utallige hjemmesider, Youtubevideoer og fansites som Pottermore, WizardingWorld. ${ }^{22}$ Hertil kommer et stort materiale på Rowlings officielle hjemmeside, ${ }^{23}$ på den officielle Harry Potter-side, Mugglenet, ${ }^{24}$ HPANA (Harry Potter Automatic News Aggregator), ${ }^{25}$ Harry Potter fandom-siden ${ }^{26}$ (der 19.11. 2019 tæller 16.308 sider), The Leaky Cauldron, ${ }^{27}$ og mange, mange andre sider, herunder utallige fanfiktion-sider samt hjemmesider der fokuserer på religiøst indhold eller religiøse læsninger af The Potterverse, såsom Harry Potter for Seekers ${ }^{28}$ eller podcasten Harry Potter and the Sacred Text. ${ }^{29}$ Dertil kommer at Harry Potter som wiki-opslag har sin helt egen Wikipedia-portal med utallige undersider.

Den lille bog Fantastic Beasts and Where to Find Them blev udgivet i 2001 på forlaget Bloomsbury ${ }^{30}$ - som også udgiver de øvrige Harry Potter-romaner - under det pseudonyme forfatternavn Newt Scamander. Den findes i mindst to udgaver, hvor jeg her kigger på 2018-udgaven med grønt omslag og tegninger af monstre ("fantastic beasts") på forside og bagside. ${ }^{31}$ Forsidemonsteret er indrammet i en gylden ramme

21 Jeg vil her tillade mig at antage at bogseriens fortælleunivers og hovedindhold er alment kendt.

22 https://eur.shop.pottermore.com/; https://www.wizardingworld.com/

23 https://www.jkrowling.com/

24 https://www.mugglenet.com/

25 https://hpana.com/

26 https://harrypotter.fandom.com/wiki/Main_Page

27 http://www.the-leaky-cauldron.org/

28 http://harrypotterforseekers.com/

29 https://www.harrypottersacredtext.com/

30 Bogen blev udgivet mhp. på at samle ind til godgørende formål; Rowling har således doneret sine royalties til organisationen Comic Relief (https://www.comicrelief.com/) og sin egen velgørenheds-organisation Lumos. Salget havde i 2016 if. Rowlings hjemmeside https://www.jkrowling.com/charity/comicrelief/ indbragt over 17 mio. engelske pund til disse to velgørende formål.

31 Den oprindelige 2001-udgave med rødt omslag har et mere tydeligt og enkelt skolebogs-look uden tegninger. Den er særlig ved at have et forord fiktivt tilskrevet Albus Dumbledore (og ikke som 2018udgaven et forord af den fiktive forfatter Scamander), samt ved at indeholde adskillige 'håndskrevne' trykte skoleskriblerier af Harry Potter, Ron Weasley og Hermione Granger, men ingen af de øvrige tillæg fra 2018-udgaven. Læseren opfordres således til at forstå at man her holder Harry Potters egen version af Scamanders bog i hånden. Men da de håndskrevne noter tydeligt er trykte og dvs. masseproducerede, fungerer grebet mindre godt end de grænse-udvisknings-greb der anvendes 
som det er ved at kravle ud af, som en indikation af at bogens monstre ikke kan holdes indfanget af bogen, men er på vej ud i denne verden. Den reelle forfatter er J.K. Rowling; dette fremgår imidlertid ikke af forsiden men kun af inderomslaget, og således signaleres allerede her et dobbeltperspektiv på hverdagsverdenen og den fiktive eller symbolske verden. Inderomslaget fremhæver i samme stil at forlaget ikke kun er forlaget Bloomsbury i den reelle ('Muggler'-) verden, beliggende i New York, London, m.fl. hovedstæder, men at udgivelsen er foregået "in association with" forlaget Obscurus Books, 18a Diagon Alley, London. Bogen giver altså et parallelt magikerforlag og en parallel magikeradresse. Samme perspektiv følger på bogens første sider. Det første afsnit i bogen er et forord af forfatteren, hvorunder der er trykt en håndskriftslignede sætning på en måde, så det ligner forfatteren Scamanders egne håndskrevne noter: "To appear only in 'For Wizards' version'", hvilket tydeligt indikerer til læseren at vedkommende holder en wizards' version i hånden. Forordet forklarer den grundlæggende to-verdens-struktur med magiker vs. mugglerverden, som Potter-universet er kendt for, samt at Ministeriet for Magi har tilladt en nyudgivelse af bogen under forudsætning af at Scamander ville forsikre Muggle-læsere om at bogen var fiktion (Rowling 2018 [fiktiv forfatter: Scamander], x). Forordet arbejder således meget eksplicit med at forstyrre, udviske eller tilmudre en klar distinktion mellem den teksteksterne og den tekstinterne verden. Endvidere refereres der til begivenheder $\mathrm{i}$ den tekstinterne verden, der fremstilles som historiske begivenheder fra 1920 'erne, der er skrevet journalistik og nyhedsartikler om i den magiske verden, som Scamander nu vil give sin version af (Rowling/Scamander 2018, x-xi). Sidste sætning i forordet tager et tema op, som filmene udfolder endnu mere, nemlig nødvendigheden af at magikerne "love and protect the incredible beasts with whom we share magic" (Rowling/Scamander 2018, xiii), som det ikke er vanskeligt at sætte i relation til samtidens klima- og naturbeskyttelsesbekymring. Endvidere er endnu en håndskrevet note trykt på siden nederst: "Editor's note: for Muggle edition, usual stuff: 'obvious fiction - all good fun - nothing to worry about - hope you enjoy it'", som igen tematiserer dobbeltperspektivet om samtidige begivenheder hhv. i en hverdagsog en magisk verden, og markerer at det der går som fiktion i Mugglerverdenen bestemt ikke er det i magikerverdenen. Det nævnte Muggle-edition-forord er ikke trykt i bogen, hvilket igen leger med grænserne mellem den forestillede og den reelle verden, da den læsende ikke-magiker således interpelleres som magiker.

Selve bogen indledes af en fyldig introduktion (s. xvi-xxxvi), der grundigt diskuterer de kategorimæssige grænser mellem de humane magikere og ikke-humane væsener. Resten af siderne fyldes af en alfabetisk gennemgang af fantastiske væsener (197), en About the Author-sektion (98-99), en quiz med ti spørgsmål, der kan afgøre om læseren er "...Magizoologist Material?, der tiltaler læseren som én blandt "countless young wizards" og nævner at flere af Harry Potters nærmeste venner arbejder med fantastiske væsener nu (s. 101, men unpag.), og en sektion med Further Reading, som

i 2018-udgaven. Dumbledores forord opretter alene overlap mellem den magiske verden og læserverdenen ved at anskue humor og latter som former for magi, som Mugglerne også kender (2001udgaven, s. vii). Fremstillingen af følelser som former for magi / måder at forbinde sig til det magiske plan ses i øvrigt også i Harry Potter-bogserien (jfr. Feldt 2016b). 
nævner bl.a. bøger der anbefales af Rubeus Hagrid om monstre, drager, søfolk, hippogriffer, m.m. (s. 104-105). De sidste to sider i bogen giver information om de to velgørende organisationer Comic Relief og Lumos (s. 106-107). Udover de åbenlyse interpellationer af læseren som magiker i alle disse afsnit er det særligt introduktionen der er interessant for en nærmere analyse.

Introduktionen er inddelt i følgende afsnit: About this book (s. xvi-xvii), What is a Beast? (s. xvii-xxiv), A Brief History of Muggle Awareness of Magical Beasts (s. xxivxxviii), Magical Beasts in Hiding (s. xxviii-xxxiv), og Why Magizoology Matters (s. xxxiv$x x x v$ ). De indledende afsnit framer Newt Scamander som en magikerversion af David Attenborough, en art opdagelsesrejsende i magiske væsener; han har rejst kontinenterne rundt og observeret dem i deres naturlige habitater og hans interesse er monsterbeskyttelse og -bevarelse (xvi-xvii). Vi præsenteres her for hans tilgang til og forståelse af disse 'beasts' og igen ser vi et naturbeskyttelsestema. Det afgørende i denne introduktion er den vægt, der lægges på at definitionen af 'beasts' har været omstridt i århundreder, og det kædes nøje sammen med hvilken status disse monstrøse væsener skal tildeles i den magiske verden: Hvilke af dem er "worthy of legal rights and a voice in the governance of the magical world - and which is a beast?" (s. xviii). Dette giver ekkoer af debatter i samtiden vedr. tildeling af rettigheder til dyr og ift. bevarelse af særlige naturområder. Efter opregning af adskillige fejlslagne forsøg på at skelne mellem 'beings' og 'beasts' og tydeliggørelse af det vanskelige i dette via udpegning af kontroverser om dette og af hvor usikker grænsedragningen mellem disse er, fremstår de kategoriale grænser, som den magiske verden opererer med, både kontingente og destabiliserede og reelt urimelige i forhold til de magiske væseners variation, hybriditet og evner. De humane magikere fremstår som forbundne på kryds og tværs med alle de andre mangfoldige væsener i dette univers og de hierarkiske grænser som svære at forsvare. Bogen udvisker således ikke alene grænserne mellem den tekst-eksterne og den tekst-interne verden, men også mellem det humane og det non-humane ift. status og værdi. ${ }^{32}$ Bogens indledning gør det også klart, at magien ikke giver kontrol over magiske væsener; det er altid nødvendigt at samarbejde med væsenerne, snarere end at kontrollere dem. Dette samarbejde mellem monstre og magikere fungerer kun når det er baseret på en anerkendelse af ontologisk hybriditet som påpeget af Oakes (Oakes 2003, 121, 126). Både ift. fantasy som medieform, ift. det større narrative univers, som the Potterverse udgør, og ift. den specifikke bog, der udgør forlaget for filmen, ser vi således en udviskning af grænser mellem verdener, både internt $\mathrm{i}$ den fortalte verden, mellem tekstinterne og teksteksterne verdener, samt mellem humane og nonhumane væsener.

32 Antje von Lehn påpeger at bogen bruger megen plads på definitionen af "beast", men slet ikke tager definitionen af "fantastic" eller "magical" op (von Lehn 2011, 68-69). 


\section{Filmanalyse II: mediering af religion i filmen Fantastic Beasts and Where to Find Them}

Analysen her vil først fokusere på filmens verdensstruktur og hvordan denne etableres, og dernæst på hvordan filmen etablerer former for overlap mellem de verdener den konstruerer i den diegetiske verden, og mellem den humane og den non-humane verden, samt mellem den diegetiske vs. den afilmiske verden vha. verbale og nonverbale midler. Endelig vil jeg undersøge hvordan religion - det monstrøse, magien, og klassisk religion - medieres filmisk.

\section{Verdenskonstruktion}

Bobby Alexander har foreslået at ritualer kan ses som "performances" som etablerer en overgang fra hverdagslivet til en alternativ kontekst, inden for hvilken det hverdagslige kan transformeres (Alexander 1997, 139; cf. Grimes 2000, 2006; J.Z. Smith 1987 ml.fl.), og at sådanne performances hjælper til at gøre den anden verden tilgængelig her og nu (Plate 2017, 46). Plate peger på at film fungerer på en lignende måde: de etablerer en (mindst) todelt verdensstruktur, og skaber en transition til en alternativ verden som efterfølgende påvirker den hverdagslige verden. Kameravinkler og bevægelser er med til at skabe og frame den anden verden, som bliver levende nok for os, så levende at den påvirker os, så vi føler 'vi er der' og vender delvist transformerede tilbage til denne verden (Plate 2017, 45). Et velegnet metodisk greb når man skal analysere verdenskonstruktioner i film kan være at udvælge særlige 'shots' der afslører noget vigtigt om filmens etablering af en verdensstruktur i det gennemgående narrativ via framing og selektering. Ofte vil 'the opening shot' $i$ en film være et nyttigt sted at starte (Plate 2017, 42-44). Et sådan 'shot' er åbningssekvensen i filmen Fantastic Beasts and Where to Find Them. ${ }^{33}$

Åbningssekvensen løber fra 00:05 til 01:50 og arbejder primært med non-verbal mediering. De indledende billeder med filmselskabets logo og titlen på filmen er holdt i en for fans velkendt 'magisk' skrifttype kendt fra Harry Potter-filmene - her endvidere med et af bogstaverne formet som et 'fantastic beast'. Harry Potter-filmens musikalske tema spilles under hele åbningssekvensen og aktiverer dermed det større narrative forestillingsunivers, skaber forventninger om en todelt verdensstruktur (Muggle/Magic), en kamp mellem godt og ondt, og om det godes sejr, ligesom musiktemaet for dedikerede Harry Potter-fans vil vække følelser og minder. Alle billeder holdes i mørke, dystre farver og musikken bliver stedse mere intens og dramatisk, mens mørke skyer og tordenvejrsagtige billeder skifter. Tilskueren er ikke i tvivl om at vi skal til at se mørkets kræfter på spil. Så vises et mørkt og dystert slot omgivet af tåge og skygger, hvor 5-6 troldmænd klædt i tøj og hatte i 1920er-stil står over for en enkelt troldmand med kort, hvidt, afbleget hår. Et stort lysglimt og mange flammer følger pludseligt, hvorefter den hvidhårede troldmand står alene tilbage, set fra ryggen: han har dræbt sine magiker-modstandere. Derpå skifter billedet hastigt mellem

33 Filmen er instrueret af David Yates (2016) og udkommet på Warner Brothers som led i en planlagt serie af fem film. Serien er spin-off fra Harry Potter-serien og fungerer som prequel. Filmen er produceret af J.K. Rowling som også har skrevet screenplay. 
forskellige avisoverskrifter holdt i skrifttyper og farver der antyder samme tidsperiode. Overskrifterne indikerer at den mørke troldmand Grindelwald (som vi kan slutte os til netop har myrdet 5-6 andre troldmænd) har slået til igen, at det udgør en trussel mod sikkerheden i den magiske verden, at Hogwarts er truet, at det anses for at være terror, samt at en krig med ikke-magikerne nu er mere sandsynlig, alt i mens rædselsvækkende skrig bakker overskrifternes uhygge-stemning op. Derpå zoomes ind på reklamer for fnisevand, koste m.m. i aviserne for en kortvarig 'comic relief'. Vi får også via en avisoverskrift at vide at der i USA er forbud mod at eje fantastiske væsener. Sidste overskrift der vises indikerer at Grindelwald er eftersøgt i amerikanske, engelske og franske aviser, og at modstanden mod magikere vokser støt i det ikke-magiske samfund, ligesom kameraet løber henover årstallet 1926 for mere præcist at kontekstualisere filmen historisk med verbale virkemidler i tillæg til de nonverbale. Sekvensen slutter med at kameraet flytter sig til et avis-foto af den amerikanske frihedsgudinde, som der fokaliseres fysisk ind i - tilskueren forsvinder helt enkelt ind i billedet, som så bliver til film; et enkelt greb der understøtter et overlap mellem den diegetiske og den afilmiske verden. Farverne skifter fra sort-hvide nuancer til almindelige farvetoner og gradvist mere afdæmpet og mindre dramatisk musik. Således får vi her etableret to af de grundlæggende verdener i filmen, nemlig en magisk verden, separat fra menneskeverdenen, på et andet plan, hvor troldmænd mødes og udkæmper kampe på liv og død om godt og ondt, og så en menneskelig hverdagsverden med store skibe, havet og almindelige byer som New York, som man som tilskuer er en del af. Som vi straks skal se, opererer filmen imidlertid med endnu en verden.

I filmens næste shot, som forbliver i farver, da vi befinder os i det diegetiske hovednarrativ, ser vi passagererne på skibet ankomme til New York ledsaget af munter musik. På dækket sidder hovedpersonen Newt Scamander med en kuffert. Hans påklædning er let bemærkelsesværdig uden at være direkte påfaldende ved at være holdt i mere klare farver end de øvrige passagerers tøj, som er i grå og sorte nuancer. Han taler beroligende og omsorgsfuldt til kufferten, som - gætter seeren - indeholder en række fantastiske væsener. Under blid musik panoreres ud til et fugleperspektivsbillede af New York, hvorpå vi ser Newt passere gennem tolden. Tolderen beder ham om at åbne kufferten, hvorpå Newt trykker på en "Muggle Worthy"-knap på kufferten, således at tolderen blot ser almindeligt kuffertindhold som skjorter, sokker, et ur, m.m. (FB I 01:50-03:35). Som det siden bliver klart, så indeholder Newts kuffert væsentligt mere end dette, og også væsentligt mere end et par magiske væsener. Den indeholder en større bestand af fantastiske væsener samt tilhørende udgaver af deres naturlige habitater såsom ørkener, skove, og et vandbassin. Kufferten fungerer som en blanding af en zoo og den rumlige selektering i et BBC-naturprogram, der inkluderer udvalgte dele af væsenernes naturlige levesteder, samt større mængder foder. De tre verdener kan opstilles således i sammenligning med verdensopbygningen i traditionel fantasy: 


\begin{tabular}{|l|l|l|l|}
\hline $\begin{array}{l}\text { Traditionel fan- } \\
\text { tasy }\end{array}$ & $\begin{array}{l}\text { Almindelig hverdags- } \\
\text { verden }\end{array}$ & Magisk verden & 0 \\
\hline Fantastic Beasts & $\begin{array}{l}\text { Almindelig hverdags- } \\
\text { verden }\end{array}$ & Magisk verden & Monstrøs verden \\
\hline
\end{tabular}

Efter denne verdens-etablering i indledningssekvensen giver filmen efterfølgende mange eksempler på hvordan grænserne mellem de tre verdener brydes og hvordan der etableres overlap og forbindelser mellem dem; filmen bæres i høj grad netop af disse interaktioner mellem verdener. Jeg vil nu via en analyse af hvordan religion medieres i filmen med verbale og non-verbale virkemidler diskutere nogle nøgleeksempler på, hvordan grænserne mellem verdener udviskes og der skabes overlap mellem dem.

\section{Mediering af religion i filmen}

Jeg tager udgangspunkt i en bred religionsdefinition (jfr. Gilhus \& Mikaelsson), der selvfølgelig ikke kun omfatter traditionelle, institutionaliserede religioner, men også 'det religiøse' (jfr. Stausberg 2010), religiøse bevægelser og miljøer, samt alle aspekter af lived religion og fritsvævende religiøse udtryk, forestillinger og praksisser knyttet til feltet "religion" i bredeste forstand, dvs. inklusive magi, profetier, monstrøse væsener og andre udtryk og fænomener fra det religiøse felt (jfr. Feldt 2016a+b). Baseret på ovenstående analyse af verdensstrukturen starter jeg med de monstrøse væsener og bevæger mig derfra til magi og religion.

Fremstillingen af den monstrøse parallelverden i Newts kuffert skildres i filmen tydeligt positivt både vha. verbale og non-verbale virkemidler. Den mest indgående skildring af den monstrøse verden i kufferten ses i klippet 34:45-44:39, hvor hovedpersonen Newt og hans ikke-magiker-ven, Kowalski, er på besøg hos magiker-søstrene Tina and Queenie Goldstein. Under dække af at være gået i seng i et separat værelse smutter Newt og Kowalski begge ned i kufferten, der fungerer som portal til den monstrøse verden. Den monstrøse verden er en zoologisk/teratologisk domineret samling af vildmarker ${ }^{34}$ der eksisterer parallelt med menneske- og magikerverdenen, komplet med habitater og fodringssteder der passer til hvert fantastisk væsen, og med varierende former for vildt klima - regnfulde skove, kolde snelandskaber, barske ørkenlandskaber, en bambusjungle, tordenvejr, dramatiske himle o.a. De fleste shots holdes i varme farver og der fokuseres på artsdiversitet og etablering af et beundrende og omsorgsfuldt blik i lighed med BBCs dyreprogrammer (cf. Taylor 2010, 141), hvor der stimuleres en "affective appreciation" via mediering og repræsentation af "delight and wonder in nature" (Taylor 2010, 142). Billederne ledsages af stemningsskabende musik, der understøtter fascination og beundring, ligesom alle væsenerne har smukke, klare farver, lysende øjne og fantastiske, beundringsværdige kroppe, om det er billelignende mini-monstre, gigantiske fuglemonstre, vandrende

34 Et begreb jeg har præsenteret og diskuteret fx i Feldt 2015. 
pinde eller nuttede pelsdyrsmonstre. De verbale virkemidler understreger via samtaler mellem Newt og Kowalski, at disse fantastiske væsener ikke har godt af at stå lænket og at selvom de kan virke farlige, så er de det ikke. Newt kan kommunikere sprogligt med dem og heraf fremgår det med stor tydelighed at de alle er sociale væsener, der fx kan have "attachment issues", være bange for mobning, eller have brug for at høre at "Mum's here". Newt formulerer endda sin mission lige ud som "to rescue, nurture and protect" disse væsener og at uddanne sine med-troldmænd til at forstå, at disse "fantastic beasts" bør æres og bevares (38:45).

Som scenen 34:45-44:39 skrider frem, tydeliggøres det imidlertid mere og mere vha. non-verbale virkemidler at den monstrøse kuffertverden er konstrueret: Vi vises kanthøjden på de bemalede sne-vægge, hvor vinterlandskabet hører op, vi ser indgangen til snelandskabet som en flagrende teltåbning, så de forskellige habitater fremstår netop som filmkulisser. Dette greb fungerer samtidigt som et meta-greb, der skaber en forbindelse mellem den diegetiske og den afilmiske verden ved at påpege selve det konstruerede i den interne verdenskonstruktion. I den diegetiske verden er det en særlig magi der holder denne monstrøse verden kørende; her understreger de non-verbale aspekter at den er en midlertidig, ustabil og konstrueret verden. Verbalt taler Newt om omplacering af væsenerne til deres naturlige habitater som det ønskede mål, hvilket yderligere understøtter en ret tydelig analogi til en zoologisk have eller wildlife park, samt til naturbeskyttelsesdiskurser i samtiden.

Lige inden scenen slutter, træder Kowalski ud i snelandskabet, hvor han mødes af en svævende sort skrækindjagende sky, en såkaldt Obscurus. Det er et væsen som tydeligt er knyttet til et menneske som en slags "return of the repressed" (Gilbey 2016), men med form som et spøgelse eller en sky og med effekter som en meget kraftig stormvind (0:03:40-0:03:55), samtidigt med at den omtales som et 'beast' (0:15:590:15:65; Harrison 2018, 335) og har tydeligt over-menneskelige og semi-dyriske kræfter. Fx river en Obscurus en gades brolægning op, så brostenene hvirvler i luften i 0:04:41-0:04:44; den river et banner over som om den har kløer, og dræber en politiker (0:57:04). En Obscurus' tilstedeværelse i den monstrøse kuffert-verden viser, at der er betydelige overlap og uklare grænser mellem menneskeverdenen, den magiske verden og den monstrøse verden, og at selv den negative kraft i Obscurus'en er omfattet af Newt's forstående omsorg for fantastic beasts. ${ }^{35}$ Newt får hurtigt Kowalski væk, og skynder sig videre, da han skal redde de fantastiske væsener, der er sluppet ud af kufferten, "before they get hurt". Kowalski undrer sig over omsorgen for dem frem for menneskene, da han antager at det er mere sandsynligt at de skader mennesker end at de selv bliver skadet. Newt forklarer i slutningen af scenen at de er fanget "in alien terrain, surrounded by millions of the most vicious creatures on the planet.... Humans."

35 Obscurusen er et væsen, der overlapper med alle tre verdener: Er den en del af den menneskelige verden, så tæt knyttet til den menneskelige vært som den er? Newt ser den som "a parasitical magical force that killed a child" (1:08:10-1:08:25), hvilket antyder at den er en korrumperet form af det magiske menneske. Som Harrison påpeger, så fremstilles de magiske evner her således som en kraft, der kommer meget tæt på at være et 'beast', dvs. ligesom de truende ikke-menneskelige væsener (Harrison 2018, 336). 
I denne scene formuleres således både vha. verbale og non-verbale midler et syn på de fantastiske væsener som kan relateres til det Bron Taylor har kaldt "dark green religion". Dark green religion er en term for religiøse miljøer der ser 'naturen' ${ }^{36}$ som hellig, med iboende værdi og som noget mennesket skylder omsorg og respekt, hvor man føler en forbundethed med alle livsformer og man kritiserer antropocentrisme (Taylor 2010, ix, 13-15). Men på trods af disse stærke udtryk for nødvendigheden af beskyttelse, respekt og omsorg for ikke-menneskelige dyr i medieringen af 'fantastic beasts', så fastholdes altså lige så tydeligt ${ }^{37}$ at grænserne mellem 'beasts', mennesker og magikere er uklare, konstruerede og ustabile, og at mennesker kan være fuldt ud så farlige og destruktive som fantastiske væsener og Obscurus'er. Men dette aspekt rummes også af de mørkegrønne religiøse tendenser, som Taylor har beskrevet, i det de nemlig lægger vægt på gensidig afhængighed mellem livsformer og en iboende værdi i alle livsformer, der bør beskyttes mod udnyttelse og opererer med forskellige forståelser af agens og socialitet blandt non-humane dyr. Taylor skelner mellem fire typer mørkegrøn religiøsitet - to slags animisme og to slags Gaia-religion. Det vi ser skildret her hvor de fantastiske væsener har socialitet, personlighed og bevidsthed, ligger det Taylor kalder spiritual animism nærmest: en forestilling om at ikke-menneskelige livsformer har personlighed, bevidsthed og særlige kræfter eller former for intelligens (Taylor 2010, 14-15). Samtidigt kommunikeres der klart, at disse ikke-menneskelige livsformer er truet af netop mennesket - et aspekt der taler direkte ind i samtidens antropocæn- og klimaforandrings-diskurser.

Bevæger vi os nu til medieringen af den magiske parallelverden i 1920ernes USA, så skildres den her som et fuldt fungerende parallelsamfund med politikere, politi og andre institutioner, som vi fx ser det i scenen 0:57:32-1:02:03. Frem til denne scene har vi fået kortere glimt af den amerikanske magiske verden via dens lokale repræsentant Tina Goldstein, som er lavt placeret i et større bureaukrati. Disse glimt viser en magisk verden, der er hierarkisk ordnet, gennemkontrolleret, meget optaget af holde den magiske verden hemmelig for ikke-magikerne (No-Maj's), og styret af magtglade personer, mens venlige og nysgerrige, åbentsindede personer som Tina degraderes eller er uden reel magt. I den her udvalgte scene vises først et "Magical Exposure Threat Level"-instrument, som angiver faren for magical exposure (dvs. afsløring af den magiske verden for ikke-magiske mennesker) som "Emergency"-level. Dernæst vises et amerikansk udseende logo på gulvet, som vi fra fugleperspektiv ser Tina passere henover med Newts magiske kuffert i hånden. Hun træder ind i The Magical

36 Naturbegrebet er blevet omfattende kritiseret (for et lille overblik, se Taylor 2005; se også Harvey 2012). De grønne miljøer Taylor taler om, refererer til kontekster i hvilke miljøbevidste og -bekymrede akademikere, aktivister, borgere m.m. mødes og påvirker hinanden. Termen "the environmentalist milieu" er delvist lånt fra Colin Campbells gamle term "the cultic milieu", som han anvendte til at betegne dele af vestlige samfund i hvilke modkulturel viden, spiritualitet o.a. dyrkedes, gensidigt befrugtede hinanden og reproduceredes i en eklektisk bricolage (Taylor 2010, 14). Christopher Partridge har anvendt samme udtryk om alternativ spiritualitet (the occultic milieu, Partridge 20042006), og peget på en gensidig befrugtning/feedback loops mellem disse miljøer og populærkulturen. Noget lignende gør sig gældende ift. dark green religion (se her Taylor 2010, 13-15, kap. 6 o.a.)

37 Særligt obscurus'en udvisker linjerne mellem dyr, menneske og magiker. 
Congress of the United States of America, hvor man netop har besøg af magiske repræsentanter fra hele verden, og man diskuterer den onde troldmand Grindelwalds flugt fra Tyskland. Vha. non-verbale virkemidler fremstilles en gammeldags udseende retssal med adskillige tilhørerpladser, som alle er besat af troldmænd og hekse fra hele verden. Trods Tinas gode intentioner ender scenen med at hun, Newt og Kowalski fængles af den kvindelige leder af den amerikanske magiske verden. Det bliver hurtigt tydeligt, at den magiske verdens ledere ikke forstår og anerkender de to helte, der nærer omsorg for de fantastiske væsener. Den magiske verdens ledere forstår ikke at skelne mellem en Obscurus og andre magiske væsener, men mener at alle fantastiske væsener er farlige og bør dræbes eller domineres af humane magikere. I en dramatisk scene bønfalder Newt lederne om ikke at gøre skade på de fantastiske væsener i kufferten, da han føres væk - uden held. Mens de sidder i deres fængselscelle forklarer Newt og Tina Kowalski hvad en Obscurus er: Det er et væsen, der kan opstå, når en magiker undertrykker sine magiske kræfter; det fremkalder en ustabil, uregerlig, mørk kraft, der kan bryde ud og angribe (Tinas ord, 1:02:03). Vi får dermed en tydelig indikation af, at undertrykkelse af magiske kræfter er noget negativt og destruktivt. Klippet gør det tydeligt at den magiske verden langt fra er fri for fejl, og at den også kan fungere undertrykkende og autoritært, samt at den opererer ekstremt racebevidst ift. eksklusion af ikke-magikerne (No-Majs). Den spirende romance mellem Kowalski og Tinas søster understøtter yderligere den positive fremstilling af hybriditet og 'raceblanding' mellem magikere og ikke-magikere.

Traditionel religion skildres i filmen via gruppen Second Salemers, ${ }^{38}$ som Newt møder første gang da han er på vej ind i banken for at fange sin Niffler (et magisk væsen), hvor gruppen missionerer foran banken (0:05:00-00:06:48). Den kvindelige leder fremstår forstokket og snæversynet; det ses i den alvorlige missionstale der advarer mod alle moderne opfindelser (såsom fx elektricitet) og om at hekse usynligt færdes blandt menneskene, at magi er destruktivt, og at borgerne må stå sammen om at bekæmpe den. Hun taler i et bibelsk sprog (fx "heed my warning") og en stemning af konflikt mellem Second Salemers og hekse- og magi-verdenen manes frem. Gruppen fremstilles (over-)tydeligt som et billede på en mørk, dyster, undertrykkende og forstenet religionstype, som er autoritær, forkrøblende, moralsk forsnævret, glædesløs, og hvis repræsentanter udøver vold mod børn. Medlemmerne har navne som Credence, Modesty og Chastity; de er klædt i mørkt, puritansk udseende tøj, og de kobler deres missionsvirksomhed med en stærk modstand mod hekse og troldmænd. De tvinger de fattige og hjemløse, som de deler mad ud til, til at missionere som tak for mad. Scenen umiddelbart efter fængslingen af Newt, Tina og Kowalski skifter til skildringen af disse 'religiøse' Second Salemers (1:02:43-1:03:26). Her ser vi en pige på ca. 8-9 år synge en spotteremse mod hekse med mange detaljer om, hvordan de skal myrdes og dø, og der optegnes således en skarp konflikt mellem magikere og denne

38 Navnet refererer naturligvis til heksejagten i Salem i slutningen af det 17. århundrede (se fx Davies 2016) og med sin reference til reelle historiske begivenheder fungerer det som en strategi til at skabe overlap mellem den afilmiske og den diegetiske verden, samt til en udbredt negativ diskurs om magi (Stratton 2007). 
religiøse gruppe, samt øvrige No-Maj-mennesker. Scenen foregår i et mørkt og dystert missionshus, hvor en gruppe børn serveres et måltid mad som de spiser med stor alvor og i stilhed. De kigger ned i bordet som om de er bange for en ukendt straf. En ung pige i 20'erne holder øje med dem og formaner dem om at missionere som tak for maden, og om at dele alle deres pamfletter ud og ikke smide nogle af dem væk, samt om at rapportere mistænkelige hændelser til hende. Kameraet fokuserer da på karakteren Credence som står i et hjørne klædt i mørkt bedemandslignende tøj - en tydelig kandidat til en magiker, der undertrykker sin magi og derfor kan producere en Obscurus, som vi netop har hørt om. Filmen præsenterer endvidere flere andre eksempler på hvordan Credences magi undertrykkes og flere eksempler på børnemishandling i missionshuset, herunder særligt mishandling af Credence. Også her får vi eksempler på, hvordan den magiske verden og den ikke-magiske verden ikke kan adskilles klart; magi findes tydeligvis også blandt Second Salemers; filmens klareste (og ret stereotype) billede på traditionel, organiseret religion. ${ }^{39}$ Credence's Obscurus er det mest slående eksempel på at grænserne mellem den menneskelige, den magiske, og den monstrøse verden ikke kan opretholdes.

\section{Diskussion}

Analysen har gjort opmærksom på en udviskning af grænser mellem denne verden og den anden verden internt i dette bog- og filmunivers, mellem den afilmiske og den diegetiske verden, samt mellem humane og non-humane aktører. Disse aspekter kan for det første relateres til en bredere udvikling i relationerne mellem fiktion og religion i vesten siden det 19. århundrede, som Michael Saler har skrevet om. Saler argumenterer for, at en bredere social forandring har gjort, at læsere er "habituated to see narratives as complex, provisional, and pragmatic, rather than as transparent, essential, and unchanging" (Saler 2012, 3-23). ${ }^{40}$ Det er blevet mere almindeligt at antage, at fiktive universer og normative virkeligheds-tolkninger og identiteter er foreløbige konstruktioner, samt at mediebrugernes egen virkelighed også er en blanding af det virtuelle og det reelle. Strukturerne i det som Saler kalder "the new public spheres of the imagination" har med andre ord fået vestlige publikummer til at omfavne virkelighedskonstruktioners og -fortolkningers kontingens (Saler 2012, 19). Han understreger at det er almindeligt for "virtual-world-users" selvrefleksivt at bebo både den reelle og den fiktive verden på samme tid, og at brugerne finder nydelse $\mathrm{i}$ at se verdenerne interagere. Dette kan kobles ikke alene til det faktum at virtuelle verdener er alment tilgængelige og spiller en socialt betydningsfuld rolle via internettets udbredelse, men også fantasy-genrens store udbredelse i samtidens vestlige mediekultur

\footnotetext{
${ }^{39}$ Forfatter og instruktør har givetvis her set en oplagt kobling til den mest kendte heksejagt i Nordamerika, samt en mulighed for at forankre fortællingen historisk og lokalt på måder der støtter grænseudviskningen mellem verdener og omvendingen af fortegn i diskursen om hekse og magi i Harry Potter-universet i øvrigt.

40 Jeg anvender også Salers pointer i en analyse af Harry Potter-romanerne (Feldt 2016a). Denne diskussions pointer overlapper delvist med samme.
} 
med dens fokus på en dobbelt opmærksomhed på flere verdener på én gang. Endvidere kan dette forbindes til Plates pointer om filmmediets stimulering af en delt opmærksomhed mellem den diegetiske og den afilmiske verden. Således er der mediekvaliteter i filmgenren, i internetbårne medier, samt i fantasy som medieform, der understøtter tilgange til og forståelser af religiøse udtryk, som vi ikke altid forbinder med kategorien religion, og som indebærer en større afslappethed ift. religiøse udtryks kontingens, et dobbeltperspektiv på religiøst indhold, der er anderledes end et syn på religion som noget der har at gøre med sandhedspostulater. Sådanne fantasyværker som Harry Potter-serien eller knopskuddet Fantastic Beasts and Where to Find Them katalogiseres som fiktion, men har alligevel en bredere religiøs signifikans og de bebos i "public virtual worlds" længe efter historien er fortalt (jfr. Saler 2012, 28). De fungerer ikke via Coleridge's "willing suspension of disbelief," men snarere via det som Saler kalder "the willing activation of pretence" (Saler 2012, 28-32), eller hvad vi også kunne kalde en "knowing refusal to let veracity claims get in the way" (Segal 2013, 50). Sådanne fantasynarrativer tilbyder virtuelle verdener som kan bebos midlertidigt, hvor der reflekteres over forskellige virkelighedsplaner, hvor man underholdes og pirres af hvad man kunne kalde "special effect religion", dvs. aspekter af religion som er maksimalt sanse- og følelsesstimulerende, opsigtsvækkende og underholdende, ud fra hvilke man kan hente individualiserede bidder af religion, myte og magi som fritidsfornøjelse, og hvor man stimuleres til at se hverdagen gennem en dobbelt linse. Magien og det monstrøse fremstår cool, spændende, fascinerende, og følelsesmæssigt dragende, mens klassisk religion fremstilles som undertrykkende, autoritær og kedelig.

Religion med stort $\mathrm{R}$ er nogle gange blevet set som noget, der sættes igennem af traditionelle autoritetsfigurer, som noget der er klart afgrænset fra andre fænomener eller sektorer, og som har en aura af seriøsitet, sandhed og virkelighed, ${ }^{41}$ og som noget der er mindre autentisk, jo mere det er blandet med andre ting. ${ }^{42}$ I modsætning til sådanne forestillinger om 'ren' religion har Ingvild Gilhus og Steven Sutcliffe argumenteret for at New Age-religionsformer er sammensatte og blandede med mange andre ideer og praksisser relateret til andre samfundssektorer (Sutcliffe \& Gilhus 2013, 11-12). I samtidens populærkulturelle medier, ligesom i New Age-miljøerne, blandes religiøst indhold også med andre ting, og Gilhus og Sutcliffes henvisning til religion som et flydende kulturfelt (og ikke som en afgrænset sektor) giver god mening (Sutcliffe og Gilhus 2013; Feldt 2016a + b). Hvis vi ser religion som et flydende kulturfelt, så rummer det både traditionelle, institutionaliserede religioner (religion med stort R), religiøse grupper, bevægelser og netværk, samt den bredere samfundsmæssige diskurs relateret til 'religion', religiøse udtryk og fænomener. Her finder vi også fortællinger om religion, overmenneskelige kræfter og magter og forskellige religiøse handlinger og fænomener i populærkulturelle medier, med varierende værditilskrivning, brug og status. I samtiden ser vi så - som bl.a. vist i denne artikel - en

41 Her mener jeg primært i en bredere offentlighed, men se fx også tendenserne i Markus Davidsens artikel i temanummeret af Religion 2016.

42 Se her fx Suzanne Kaufmanns meget interessante analyse af helligt og profant i 1800-tallets Lourdes (2009). 
række teknologiske udviklinger inden for bestemte medier, samt et andet udbredelsesmønster, der har og formodentlig vil få yderligere indflydelse på det religiøse felt som helhed. Den indflydelse går i en retning, hvor klassiske ideer om tro, dyb afhængighed, og virkeligheds- og sandheds-tilskrivning ikke altid er passende. I stedet er det følelser, sansestimulerende oplevelser, og hverdagens behov, og et dobbelt perspektiv på religion som noget man kan gå ind og ud af og beskæftige sig med en gang i mellem som fritidsfornøjelse, der er i fokus; det vil sige skiftende og delvise engagementer i "det religiøse." Forståelser af religion som enheder, der defineres organisatorisk, og som relativt stable samlinger af forestillinger og praksisser, er ikke dækkende for hele dette felt, og vel næppe heller for historiske varianter af forholdet mellem religion og populærkulturelle medier.

Den popularitet som religiøst indfarvede special effect-maksimerende oplevelser af 'det religiøse', forbrug af mystik og mysterier, magi og fascinerende monstre i samtidens populærkulturelle medier og multimediale fantasyfiktion, i kombination med brugen af de relaterede virtuelle verdener på multimedieplatforme, indikerer at dette felt har en bredere social signifikans. Et populært forbrug af religiøs kommunikation, religiøse fænomener og udtryk kan foregå blandet sammen med institutionaliserede Religioner eller nye religiøse bevægelser, uafhængigt af dem eller i konflikt med dem. Man kan forestille sig, at den fortsatte vækst i overnaturlig fantasyfiktion, der relaterer sig til religion, i samtidens vestlige mediekultur vil fremme særlige former for socialt liv i relation til religion; med andre ord er det nærliggende at mediekulturen på sigt kan påvirke det religiøse felt. Udviklingen kan muligvis bidrage til en svækkelse af almene forståelser af religion som noget absolut, seriøst og som uforanderlig sandhed, i retning af forståelser af og engagementer i religion som noget kontingent, foranderligt og underholdende.

Analysen har for det andet peget på en optagethed af at udviske grænserne mellem det humane og det non-humane på måder som underminerer modernistiske, skarpe grænser mellem 'natur' og 'kultur'. Her spiller filmen op imod samtidens diskussioner om klima, relaterer til de grønne religiøse miljøer, og kobler sig implicit til nyere teoretiseringer af forholdet mellem natur og kultur hinsides et modernistisk naturbegreb (som fx Donna Haraways 'naturkultur'-begreb (Haraway 2003). Udviskningen af grænser mellem det humane og det non-humane kan imidlertid også forbindes til udviklingen i samtidens mediekultur. Kritikken af det modernistiske naturbegreb og den dertil hørende antropocentrisme samt af en skarp skelnen mellem natur og kultur har fået momentum i den 'antropocæne' tidsalder; ${ }^{43}$ men som den italiensk-australske filosof Rosi Braidotti påpeger, så er antropocæn (hvis dette er en passende term) også en æra i hvilken omfanget af teknologisk og virtuel mediering er enormt. Så en klassisk (også i princippet grund-humanistisk) antropocentrisme udfordres ikke alene af nye forståelser af forholdet til vores ikke-menneskelige omgivelser og udvidelsen af aktørbegrebet, der i stedet sætter et kontinuum af naturkulturer, men også

43 Som Anders Blok har påpeget, så er Antropocæn en favoritterm blandt ny-materialister som Nigel Clark, Geoffrey Harman og Timothy Morton; Blok ser STS og ANT's revitalisering af Gaia-figuren som et mere frugtbart og adækvat perspektiv (Blok 2019). 
af udviklingen i mediekulturer og -teknologier. Netop skiftet til naturkulturer (Haraway 1997, 2003) kunne derfor erstattes af et fokus på et kontinuum af medienaturkulturer, som Braidotti foreslår. Menneskers liv er præget af medieringspraksisser og apparater, som gør teknologi til second nature, og vores omgivelser til et 'tekno-økologisk miljø' (Braidotti 2016). Sådanne forbindelser mellem vores ikke-menneskelige miljø/omgivelser, teknosfæren og nye medier omformer spørgsmålet om alteritet, andethed, på måder som netop som FB I synes også at italesætte.

\section{Konklusion}

Denne artikel har diskuteret religion og medier ud fra en analyse af et eksempel på religion i populærkultur, nemlig den Harry Potter-relaterede bogudgivelse Fantastic Beasts and Where to Find Them (2001), og den senere filmatisering instrueret af David Yates med screenplay af J.K. Rowling (2016), der knytter sig til bogen. Artiklen har præsenteret en religionsvidenskabelig, mediefokuseret tilgang til filmanalyse, der inkluderer både verbale og non-verbale medierings-aspekter. Analysen har behandlet verdenskonstruktion i filmen samt mediering af religion (hhv. traditionel religion, magi og det monstrøse) i det filmiske univers, og argumenteret for at populærkulturelle medier udgør en vigtig arena for forståelse af det religiøse felt i samtiden, og at denne arena bør behandles religionsvidenskabeligt, da den både afspejler og former religiøse forandringer i samtiden. Analysen viste, at filmen indlejrer sig i en bredere populærkulturel trend, hvor traditionel religion fremstilles som forstenet og autoritær, mens magi, monstre og grøn religion fremstilles positivt og tiltrækkende. Samtidigt understøttede filmens medialitet en udviskning af grænserne mellem verdener, både i den tekst-interne verdensstruktur, dvs. i dette tilfælde mellem en menneske-, en magiker- og en monstrøsitets-verden, samt mellem den diegetiske og den afilmiske verden. Endvidere tematiserede filmen i bredere forstand uklare grænser og overlap mellem den humane og den non-humane verden, der spiller ind i samtidens grønne religiøse tendenser.

\section{LITTERATUR}

Alexander, Bobby C.

1997 "Ritual and Current Studies of Ritual: Overview", in Stephen D. Glazier, ed., Anthropology of Religion: A Handbook, Westport, Connecticut: Greenwood Press, 139-160.

Blok, Anders

2019 "Planetære perspektiver. Antropocæn, Kapitolocæn, Gaia?", Turbulens. Forum for samtidsrefleksion. Temanummer om antropocæn, februar 2019. Online: http://turbulens.net/temaer/antropocaen/

Braidotti, Rosi.

2016 “The Critical Posthumanities, or Is Medianatures to Naturecultures as Zoe is to Bios?", Cultural Politics 12/3, 380-390. https://doi.org/10.1215/17432197-3648930

Damasio, Antonio

1994 Descartes' Error: Emotion, Reason, and the Human Brain, New York: Putnam.

Davidsen, Markus, ed. 
2016 Special issue af Religion: Fiction and Religion. Med bidrag af Markus Davidsen, Anders K.

Petersen, Dirk Johannsen, Carole Cusack og Laura Feldt.

Davidsen, Markus

2010 "Fiktionsbaseret religion - fra Star Wars til Jediisme", Religionsvidenskabeligt Tidsskrift 55, 3-21. https://doi.org/10.7146/rt.v0i55.4017

Davies, Owen

2016 America Bewitched. The Story of Witchcraft After Salem, Oxford: Oxford University Press.

Feldt, Laura

2020 "Fictioning Myths and Mythic Fictions: The Standard-Babylonian Gilgameš Epic and Questions of Heroism, Myth, and Fiction", in Nickolas Roubekas og Thomas Ryba, eds., Interpreting and Explaining Religion \& Myth, Method and Theory in the Study of Religion Series, Leiden: Brill, 13 sider. Udkommer november 2020.

2016a "Contemporary fantasy fiction and representations of religion: playing with reality, myth, and magic in His Dark Materials and Harry Potter", Religion 46/4, 550-574. https://doi.org/10.1080/0048721X.2016.1212526

2016b "Harry Potter and Contemporary Magic - Fantasy Literature, Popular Culture, and the Representation of Religion", Journal of Contemporary Religion 31/1, 101-114. https://doi.org/10.1080/13537903.2016.1109877

2015 "Wilderness", in Kocku von Stuckrad og Robert A. Segal, eds., Vocabulary for the Study of Religion, Leiden: Brill.

2012 The Fantastic in Religious Narrative from Exodus to Elisha, London: Routledge.

2011 "Religious narrative and the literary fantastic: Ambiguity and uncertainty in Ex 1-18, Religion 41/2, 251-283. https://doi.org/10.1080/0048721X.2011.570798

2006 "Signs of Wonder - Traces of Doubt: The Fantastic in the Exodus Narrative", in N. Hömke \& M. Baumbach, eds., Fremde Wirklichkeiten. Literarische Phantastik und antike Literatur. Universitätsverlag Winter, 311-338.

Feldt, Laura \& Jan N. Bremmer, eds.

2019 Marginality, Media and Mutations of Religious Authority in the History of Christianity, Studies in the History and Anthropology of Religion 6, Leuven: Peeters.

Feldt, Laura \& Armin W. Geertz

2020 "Religion og medier i et religionsvidenskabeligt perspektiv", Religionsvidenskabeligt Tidsskrift 70.

Fields, Karen

1995 "Translator's Introduction: Religion as an Eminently Social Thing", in Emile Durkheim, The Elementary Forms of Religious Life, trans. K. Fields, New York: The Free Press, xviil-xxiii.

Flood, Gavin

1999 Beyond Phenomenology. Rethinking the Study of Religion, University of Michigan: Cassell.

Geertz, Armin W.

1999 "Definition as an Analytical Strategy in the Study of Religion", Historical Reflections/Reflexions Historiques 25/3, 445-475.

Geertz, Clifford

1977 “Religion as a Cultural System” in M. Banton, ed., Anthropological Approaches to Religion, ASA Monographs 3, London: Tavistock Publications, 1-46.

Gilbey, Ryan

2016. "Is Fantastic Beasts a stretch too far for JK Rowling's imagination?", New Statesman 18. nov. 2016. Url: https://www.newstatesman.com/culture/film/2016/11/fantastic-beasts-stretch-too-farjk-rowlings-imagination

Gilhus, Ingvild \& Lisbeth Mikaelsson

2001 Nyt blikk på religion. Studiet af religion i dag [New Perspectives on Religion: The Study of Religion Today], Oslo: Pax.

Grieser, Alexandra \& Jay Johnston 
2017 The Aesthetics of Religion - A Connective Concept, Berlin: De Gruyter. (Religion and Reason, Bind 58). https://doi.org/10.1515/9783110461015

Grimes, Ron

2006 Rite Out of Place, Oxford: Oxford University Press. https://doi.org/10.1093/acprof:oso/9780195301441.001.0001

2000 Deeply Into the Bone, Berkeley: University of California Press.

Haraway, Donna

2003 The Companion Species Manifesto, Chicago: Prickly Paradigm Press.

Harrison, Jen

2018 "Posthuman Power: The Magic of Hybridity in the Harry Potter Series", Children's Literature Association Quarterly 43/3, 325-343. https://doi.org/10.1353/chq.2018.0037

Harvey, Graham

2012 "Ritual is Etiquette in the Larger than Human World: the two wildernesses of contemporary Eco-Paganism", in Laura Feldt, ed., Wilderness in Mythology and Religion. Approaching Religious Spatialities, Cosmologies and Ideas of Wild Nature, Religion and Society 55, Berlin: Walter de Gruyter, 265-292.

Hjarvard, Stig og Mia Lövheim, red.

2012 Mediatization and Religion. Nordic Perspectives, Göteborg: Nordicom.

Hjarvard, Stig

2012 "Three Forms of Mediatized Religion", in idem \& Mia Lövheim, eds., Mediatization and Religion. Nordic Perspectives, Göteborg: Nordicom, 21-44.

Kaufmann, Suzanne

2009 "Religion and modernity: The Case of the Lourdes Shrine", in P.L. Caughie, ed., Disciplining Modernism, Palgrave MacMillan, Basingstoke, 92-108. https://doi.org/10.1057/9780230274297_6

Kelso, Sylvia

2007 "The God in the Pentagram: Religion and Spirituality in Modern Fantasy", Journal of the Fantastic in the Arts 18/1, 61-82.

Lachmann, Renate

2002 Erzählte Phantastik. Zu Phantasiegeschichte und Semantik phantastischer Texte, Frankfurt am Main: Suhrkamp.

Lied, Liv Ingeborg

2012 "Religious Change and Popular Culture with a Nod to the Mediatization of Religion Debate", in Stig Hjarvard \& Mia Lövheim, eds., Mediatization and Religion: Nordic Perspectives, Göteborg: Nordicom, 183-201.

Lövheim, Mia

2012 "A Voice of Their Own. Young Muslim Women, Blogs and Religion", in Stig Hjarvard \& Mia Lövheim, eds., Mediatization and Religion: Nordic Perspectives, Göteborg: Nordicom, 129-145.

2011 “The Mediatisation of Religion. A Critical Appraisal”, Culture and Religion 12/2, 111-117. https://doi.org/10.1080/14755610.2011.579715

Mahan, Jeffrey

2014 Media, Religion and Culture - An Introduction, London: Routledge. https://doi.org/10.4324/9781315777061

McGuire, Meredith

2008 Lived Religion. Faith and Practice in Everyday Life, Oxford: Oxford University Press.

McLuhan, Marshall

1994 Understanding Media: The Extensions of Man, [1964], New York: McGraw-Hill.

Meyer, Birgit

2014 "Mediation and the Genesis of Presence" (reprint of inaugural lecture), with a response on comments by Hans Belting, Pamela Klassen, Chris Pinney, Monique Scheer. An Author Meets Her Critics - Around Birgit Meyer's “Mediation and the Genesis of Presence: Toward a Material 
Approach to Religion", Religion and Society: Advances in Research 5, 205-254.

https://doi.org/10.3167/arrs.2014.050114

Meyrowitz, Joshua

2001 "Morphing McLuhan: Medium Theory for New Millennium", Proceedings of the Media Ecology Association 2, 8-22.

1994 "Medium Theory", in D. Crowley \& D. Mitchell, eds., Communication Theory Today, Cambridge: Polity Press, 50-77.

Morgan, David

2012 The Embodied Eye: Religious Visual Culture and the Social Life of Feeling, Berkeley: University of California Press. https://doi.org/10.1525/california/9780520272224.001.0001

2011 "Mediation or Mediatisation: The History of Media in the Study of Religion", Culture and Religion 12, 137-152. https://doi.org/10.1080/14755610.2011.579716

Oakes, Margaret J.

2003 "Flying Cars, Floo Powder, and Flaming Torches: The Hi-Tech, Low-Tech World of Wizardry", in Giselle Liza Anatol, ed., Reading Harry Potter: Critical Essays, Westport, CT: Praeger, 117-28.

Paden, William

1994 Religious Worlds. The Comparative Study of Religion, Boston: Beacon.

Partridge, Christopher

2004-2006 The Reenchantment of the West. Alternative Spiritualities, Sacralization, Popular Culture and Occulture, Vol. I., London: T\&T Clark.

Petersen, Anders K.

2005 "Fra hellig til religiøs tekst", in Ole Davidsen, Kirsten Nielsen og Stefan Klint, eds., Litteraturen og det hellige, Aarhus: Aarhus Universitetsforlag, 414-432.

Plate, Brent

2017 Religion and Film. Cinema and the Re-Creation of the World, 2. ed., New York: Columbia University Press. https://doi.org/10.7312/plat17674

2012 "The Skin of Religion: Aesthetic Mediations of the Sacred", CrossCurrents 06, 62/2, 162-180. https://doi.org/10.1111/j.1939-3881.2012.00228.x

Ricoeur, Paul

1975 The Rule of Metaphor. Multi-disciplinary Studies of the Creation of Meaning in Language, Toronto: University of Toronto Press.

Rowling, J.K.

2001 Fantastic Beasts and Where to Find Them, 2. ed. 2018. London: Bloomsbury.

Rowling, J.K. \& David Yates

2016 Fantastic Beasts and Where to Find Them. (Screenplay J.K. Rowling /instruktør David Yates), 132 min. Warner Brothers.

Saler, Michael T.

2012. As If. Modern Enchantment and the Literary Prehistory of Virtual Reality, Oxford: Oxford University Press.

Scamander, Newt

2001 Se Rowling, J.K. 2001.

Schaefer, Donovan

2015 Religious Affects: Animality, Evolution, and Power, Durham: Duke University Press. https://doi.org/10.1215/9780822374909

Segal, Robert A.

2013 "The Blurry Line between Humans and Gods", Numen - International Review of the History of Religions 60, 39-53. https://doi.org/10.1163/15685276-12341251

Simonis, Anette

2005 Grenzüberschreitungen in der phantastischen Literatur: Einführung in die Theorie und Geschichte eines narrativen Genres, Heidelberg: Universitätsverlag Winter. 
Smith, Jonathan Z.

1987 To Take Place. Towards Theory in Ritual, Chicago: University of Chicago Press.

Stausberg, Michael

2010 "Distinctions, Differentiations, Ontology and Non-Humans in Theories of Religion", Method E Theory in the Study of Religion 22/4, 354-374. https://doi.org/10.1163/157006810X531139

Stratton, Kimberley

2007 Naming the Witch. Magic, Ideology and Stereotype in the Ancient World, New York: Columbia University Press. https://doi.org/10.7312/stra13836

Sutcliffe, Steven \& Ingvild Gilhus (eds.)

2013 "Introduction: All Mixed Up - Thinking About Religion in Relation to New Age Spiritualities", in idem \& idem, eds., New Age Spirituality. Rethinking Religion, London: Acumen 1-16.

Taves, Ann \& Egil Asprem

2020 "The Building-Block Approach: An Overview", in Göran Larsson, Andreas Nordin \& Jonas Svensson, eds., Building Blocks of Religion. Critical Applications and Future Prospects, London: Equinox.

Taylor, Bron

2010 Dark Green Religion. Nature Spirituality and the Planetary Future, Berkeley: University of California Press.

2005 "Introduction", in Bron Taylor, ed., Encyclopedia of Religion and Nature, London: Continuum, viixvii.

Todorov, Tzvetan

1975 The Fantastic. A Structural Approach to a Literary Genre, [1973], Ithaca: Cornell University Press.

Tolkien, J.R.R.

1964 "On Fairy Stories", in idem. Tree and Leaf, London: Allen and Unwin.

von Lehn, Antje

2011 "Harry Potter, Spiderwick and the Tradition of the Bestiary", Fastitocalon: Studies in Fantasticism Ancient to Modern 2/1-2, 63-79.

Wisker, G

2005 Horror Fiction: An Introduction, London: Continuum.

Wright, Melanie

2007 Religion and Film. An Introduction, London/New York: I.B. Tauris.

Laura Feldt, lektor, ph.d.

Religionsstudier, Institut for Historie, Syddansk Universitet 